\title{
Increase of flood water levels on the middle Danube
}

\section{PAVLA PEKAROVA ${ }^{1}$, PAVOL MIKLANEK ${ }^{1}$ \& JAN PEKAR ${ }^{2}$}

1 Institute of Hydrology, Slovak Academy of Sciences, Racianska 75, 83102 Bratislava 3, Slovak Republic miklanek@uh.savba.sk

2 Department of Applied Mathematics and Statistics, Faculty of Mathematics, Physics and Informatics, Comenius University, 84248 Bratislava, Slovak Republic

\section{INTRODUCTION}

After the flood in 1954, Pacl (1954) drew attention to the fact that throughout the Slovak section of the Danube the levels of the 1954 flooding exceeded the level of the flood in 1899 and that there was an increase of flood hazard. During the June 2013 Danube flood, the water level at the gauging station in Bratislava achieved the highest ever values. A water level of $1034 \mathrm{~cm}$ was measured on the gauge, and the measured flow was $10640 \mathrm{~m}^{3} \mathrm{~s}^{-1}$, while during the flood in 1899 the water level was about $64 \mathrm{~cm}$ lower with a flow rate of $10870 \mathrm{~m}^{3} \mathrm{~s}^{-1}$. The aim of this paper is to analyse this situation.

\section{DATA}

In a statistical analysis of long-term trends, we used a series of average daily flow and water level and a series of maximum annual flow of the Danube from Bratislava station, for the period 18762013 (Fig. 1). During this period, five floods on the Danube occurred that exceeded $10000 \mathrm{~m}^{3} \mathrm{~s}^{-1}$ in Bratislava.

\section{LONG-TERM TRENDS}

The measured mean daily and maximum annual flow series of the Danube at Bratislava station are, due to its length (138 years), extremely rare. In Fig. 1 we can see that there were seven floods exceeding $8500 \mathrm{~m}^{3} \mathrm{~s}^{-1}$ in the period 1876 to 1900 . This period is comparable with the period 1990 2014. Noteworthy is also the period 1900-1953. This 50-year period is extraordinarily quiet concerning floods; there were only two floods and they did not exceed $9000 \mathrm{~m}^{3} \mathrm{~s}^{-1}$. From the longterm point of view the growth of extreme discharges is not statistically significant for station Bratislava.

However, there is a gradual, adverse change at the top of the rating curve for the gauging profile in Bratislava - water levels are higher at the same flow. This change was dramatically demonstrated during the flood in June 2013. Water level in Bratislava exceeded the magical value of $10 \mathrm{~m}$ by $34 \mathrm{~cm}$, with flow rates comparable to flow rates in 1899 or 1954 (Table 1). A comparison of water levels shows that there is an increase at stations Hainburg, Bratislava and Budapest in the last 138 years, while the peak flows do not increase at Bratislava station (Fig. 2).

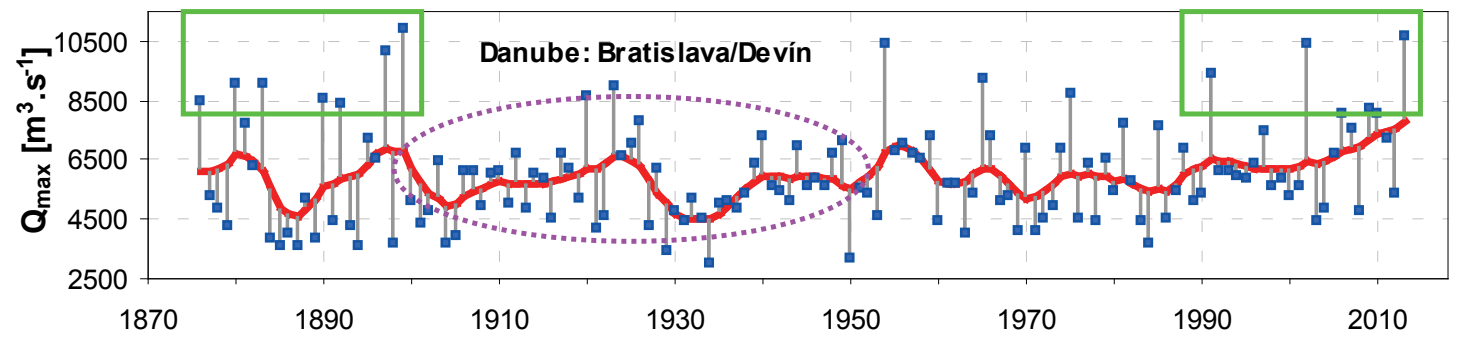

Fig. 1 Series of maximum annual flows of the Danube in Bratislava, deviations from 7-years moving averages. 
Table 1 Peak water level of the biggest instrumental floods at Bratislava (1868.8 river $\mathrm{km}$ ), discharge at Bratislava water gauge, water levels at Hainburg (1883.9 river km), and Budapest (1646.5 river $\mathrm{km})$.

\begin{tabular}{lcl|ll}
\hline Date, Bratislava & $\begin{array}{l}\text { Water level } \\
(\mathrm{cm})\end{array}$ & $\begin{array}{l}\text { Discharge } \\
\left(\mathrm{m}^{3} \mathrm{~s}^{-1}\right)\end{array}$ & $\begin{array}{l}\text { Hainburg } \\
(\mathrm{cm})\end{array}$ & $\begin{array}{l}\text { Budapest } \\
(\mathrm{cm})\end{array}$ \\
\hline 06. 06. 2013 & 1034 & 10640 & 980 & 891 \\
16. 08. 2002 & 991 & 10370 & 952 & 848 \\
15. 07. 1954 & 984 & 10400 & 906 & 807 \\
19.09. 1899 & 970 & 10870 & 862 & 770 \\
04.081897 & 940 & 10140 & 854 & 780 \\
\hline
\end{tabular}



Fig. 2 Water levels of the Danube.

\section{CONCLUSION}

Over 110 years there has been an increase in flood water levels at Bratislava by more than $60 \mathrm{~cm}$, which is a significant change. It is difficult to answer the question why there is an increase of water levels at stations on the Danube. Likely there will be more causes:

1. Reduction of the gauging cross-section because of dykes and embankment construction, in Bratislava, and upstream and downstream of Bratislava. In 1899 the city was flooded.

2. Rise of sediments and gravel accumulations in the river channel near the gauging station.

3. Another reason is that there was no dyke break in the Slovak Danube reach in 2002 and 2013. Therefore, the transformation of the flood wave was slower, and the water levels were higher compared to 1899 and 1954, when the Danube dykes were broken downstream of Bratislava (Svoboda et al. 2000, Pekarova et al. 2013, 2014).

4. Alleviation of the channel of the middle Danube downstream of Devin Gate is a natural process (Hronec 1969), resulting from changes of the Danube bottom slope (Fig. 3).

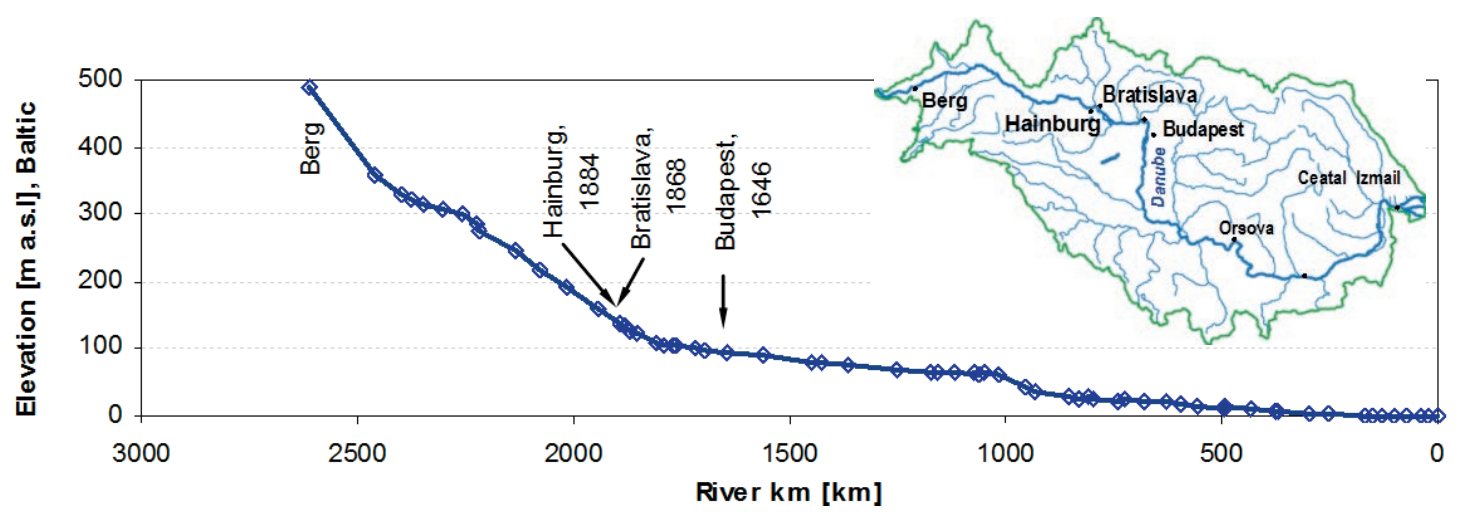

Fig. 3 Elevations of the water gauge datum of the selected stations along the Danube River.

Acknowledgements This work was supported by the MVTS "Flood regime of rivers in the Danube river basin" during the implementation of the project "the Centre of excellence for integrated flood protection of land" (ITMS 26240120004) supported by the Research \& Development Operational Programme funded by the ERDF.

\section{REFERENCES}

Hronec, Š. (ed.) (1969) The Danube Flood in 1965. Publ. House PALLAS-SFVU, Bratislava, 88 p. (in Slovak).

Pacl, J. (1954) The Danube Flood in July 1954. Hydrometeorological Institute, Bratislava, 16 p. (in Slovak).

Pekarova, P., et al. (2013) Historic flood marks and flood frequency analysis of the Danube River at Bratislava, Slovakia. J. Hydrol. Hydromech. 61(4), 326-333.

Pekarova, P., et al. (2014) Flood marks along the Danube River between Passau and Bratislava. Bratislava, VEDA, 104 pp. (http://pavla.pekarova.sk/monografie).

Svoboda, A., Pekarova, P. and Miklanek, P. (2000) Flood Hydrology of Danube between Devin and Nagymaros. Bratislava: UH SAV; SVH, 96 pp. (http://pavla.pekarova.sk/monografie). 